\title{
BMJ Open How has COVID-19 impacted the civil registration and vital statistics system in Loreto, Perú? Evidence using process mapping and qualitative analysis
}

\author{
Javier Silva-Valencia, ${ }^{1}$ Tim Adair (D) , ${ }^{2}$ John Hart (D) , ${ }^{2}$ Graciela Meza (D) , ${ }^{3}$ \\ Javier Vargas Herrera ${ }^{1}$
}

To cite: Silva-Valencia J, Adair T, Hart J, et al. How has COVID-19 impacted the civil registration and vital statistics system in Loreto, Perú? Evidence using process mapping and qualitative analysis. BMJ Open 2021;11:e055024. doi:10.1136/ bmjopen-2021-055024

- Prepublication history and additional supplemental material for this paper are available online. To view these files, please visit the journal online (http://dx.doi.org/10.1136/ bmjopen-2021-055024).

Received 30 June 2021 Accepted 03 November 2021

D) Check for updates

C Author(s) (or their employer(s)) 2021. Re-use permitted under CC BY-NC. No commercial re-use. See rights and permissions. Published by BMJ.

${ }^{1}$ Telehealth Unit, School of Medicine, Universidad Nacional Mayor de San Marcos, Lima, Peru

${ }^{2}$ Melbourne School of Population and Global Health, The University of Melbourne, Melbourne, Victoria, Australia

${ }^{3}$ School of Medicine, Universidad Nacional de la Amazonía

Peruana, Iquitos, Peru

Correspondence to

Dr Tim Adair;

timothy.adair@unimelb.edu.au

\section{ABSTRACT}

Objectives Accurate civil registration and vital statistics (CRVS) systems are the primary data source to measure the impact of the COVID-19 pandemic on mortality. This study assesses how the pandemic impacted CRVS system processes in Loreto region of Peru, one of the worst affected countries globally.

Design Qualitative study.

Setting Loreto, a remote region, which had the highest reported mortality rate in Peru during the pandemic. Participants Semistructured individual interviews and documentary analysis were conducted between September 2020 and May 2021 with 28 key informants from eight institutions involved in death certification. Key informants were identified using a purposive sampling strategy commencing at the Health Directorate of Loreto, and the snowball method was used where a participant suggested another organisation or person. Information from key informants was used to compare business process maps of the CRVS system before and during the pandemic.

Results During early May 2020, there were seven times more registered deaths than in earlier years, but key informants believed this underestimated mortality by $20 \%-30 \%$. During the pandemic, families had to interact with more institutions during the death certification process. Several issues disrupted death certification processes, including the burden of increased deaths, the Environmental Health Directorate often removing a body without the family's express agreement, the creation of COVID-19 cemeteries where no death certificate was needed for burial, greater participation of funeral homes that often used outdated paper forms, and closure of civil registry offices. There was increased use of the online National Death System (SINADEF) but many users had problems with access.

Conclusions The pandemic substantially disrupted CRVS processes in Loreto, making death certification more difficult, placing greater burden on the family and leading to more participation from unregulated organisations such as funeral homes or cemeteries. These disruptions were impacted by limitations of the CRVS system's processes before the pandemic.

\section{INTRODUCTION}

The COVID-19 pandemic has caused an unprecedented impact on health systems
Strengths and limitations of the study

- This is one of the first assessments of how the COVID-19 pandemic has impacted processes of the civil registration and vital statistics system, which should be the primary data source to measure excess mortality.

- The study was conducted in Loreto, the region with the highest reported mortality rate during the pandemic in Peru, one of the most adversely impacted countries globally.

- Key informants from several institutions involved in death certification were interviewed, providing a comprehensive description of how death certification processes were disrupted.

- The study, however, did not include the perspectives of families of the deceased.

globally. According to data from the WHO, 3.9 million deaths from COVID-19 had been reported worldwide by the end of June 2021. ${ }^{1}$ However, this figure underestimates the true impact of the pandemic, with $\mathrm{WHO}$ estimating that excess mortality from the pandemic in 2020 to be two-thirds higher than reported COVID-19 deaths. ${ }^{2}$ The primary source of accurate mortality data should be a timely and accurate civil registration and vital statistics (CRVS) system, which are a key input to inform important decisions in public health and generate adequate responses to humanitarian emergencies. ${ }^{3-8}$ However, there is uncertainty about the true impact of the pandemic on mortality because of inherent weaknesses in CRVS systems in many countries, particularly low-income and middle-income countries. According to the United Nations, only two-thirds of countries register at least $90 \%$ of all deaths that occur. ${ }^{910}$ Furthermore, in addition to the impact that the pandemic has had on all health processes, it has potentially weakened 
already suboptimal CRVS systems and led many countries to produce unreliable data on mortality.

The COVID-19 pandemic has, therefore, emphasised the need to improve vital statistics and made it imperative that each country focuses on ensuring all the necessary processes for their CRVS system to effectively register deaths. Because CRVS systems are complex, with many actors and intervening components that depend not only on the health system but also other institutions, the first step for their improvement is to carry out a mapping of processes that can help capture the complexity in CRVS systems, including the main actors and processes. There have been factors that may have significantly altered information flows and mortality recording processes to the detriment of the quality of data in CRVS systems, such as measures related to compulsory social isolation, limitation of mobility, suspension of work and increased use of online platforms; evidence of such detrimental impacts has been found in several countries. ${ }^{11} 12$

Peru has been one of the worst affected countries during the COVID-19 pandemic. The first confirmed case was notified on 6 March 2020, and the first death occurred 13 days later. The exponential increase in infections began in the city of Lima (capital of Peru); however, by 12 April 2020, cases had already been reported in all regions of the country. By May 2021, Peru ranked first worldwide in total estimated excess deaths and is the only country that exceeded the historical average forecast by more than $100 \%$ compared with recent years. ${ }^{13}{ }^{14}$ Mortality data in Peru are mainly found in two systems: The National Death System (SINADEF), which is administered by the Ministry of Health (MINSA) and is where medical death certificates are registered; and the National System of Identification and Registry of Civil Status (RENIEC) that issues death certificates with official value to carry out legal procedures. The completeness of this death registry has increased over the years, reaching approximately $80 \%$ of estimated deaths since 2016, but with further scope for improvement. ${ }^{15}$ A major explanation for incomplete data is lack of supervision of death certificate data collection. National regulations stipulate that for registration of paper medical death certificates, doctors should the certificate in two to deliver the upper part to the family members and to keep the lower part to deliver it to a dependency of MINSA (Loreto Health Directorate (DIRESA), Regional Health Management (GERESA) or Directorate of Integrated Health Networks (DIRIS)) for the data to be incorporated into SINADEF. However, many doctors give the family member the complete form without sending this information to MINSA, and the death is not registered in SINADEF. ${ }^{15}$

It may be that the COVID-19 pandemic has had a significant impact on the operation of the entire death registration system in Peru. During 2020, there were many factors that could potentially have altered how death registration processes are meant to operate as specified by existing regulations. ${ }^{16}{ }^{17}$ These include the strict national quarantine of more than 100 days, the limited availability of doctors to produce timely medical death certificates due to the overwhelming demand for health services, deaths from COVID-19 in public spaces and new regulations for the handling of bodies, burials without documentation, among others. ${ }^{18-21}$

For the government at the national and local level to track and respond to the pandemic, it must have accurate information on mortality. Measurement of excess mortality in a hard-hit country such as Peru with already suboptimal death registration is reliant on assumptions of whether completeness of registration was negatively or positively affected by the pandemic, or remained unchanged. ${ }^{22} 23$ Additionally, governments need to specifically know of the barriers to proper death notification and registration processes and how they can be rectified. To address the significant knowledge gap on this issue, this study evaluates how the COVID-19 pandemic impacted the civil registration processes and the mortality registry in Loreto region, one of the regions in Peru most affected by COVID-19. Specifically, the study's purpose is to describe how the death certification processes and the flow of information of the CRVS system changed during the COVID-19 pandemic.

\section{METHODS \\ Setting}

Loreto is one of the 24 regions in Perú. It is located in the more remote jungle area of Perú and represents $28 \%$ of the surface of the national territory with approximately 1.07 million inhabitants of Peru's population of 32.51 million. It is characterised by its great cultural diversity and the sparseness of its population, many of whom live in remote areas. As in many parts of the country, there is poor internet connectivity both in communities and in health facilities. ${ }^{24}$ It was one of the worst affected regions during the COVID-19 pandemic; during April and June, it was the region with the highest reported mortality rate and the second-highest mortality of health professionals. 2526

Loreto registered his first official case on 17 March 2020, and his first death on 30 March 2020. During the first month of quarantine, the large number of SARSCoV-2 infections destabilised the health system. It has been reported that the lack of protocols, the lack of personal protective equipment and the lack of oxygen aggravated the public health crisis in that region. ${ }^{27}$ Among the preliminary studies that have been carried out in the region, the seroprevalence studies stand out, with it being reported that until 6 June, $58.3 \%$ of the health workers of the Regional Hospital of Loreto and $54.5 \%$ of the students present were positive for COVID$19 .^{28}$ Also, on 18 July 2020 , a community seroprevalence study was published where it was found that 7 out of 10 inhabitants of the capital Loreto had already contracted the COVID-19 virus. $^{29}$

\section{Study design}

We conducted a qualitative case study using semistructured individual interviews and documentary analysis 
Table 1 Organisations participating in the study

\begin{tabular}{|c|c|c|}
\hline Name & Brief description & Location \\
\hline Ministry of Health & Governing body on health at the national level & City of Lima \\
\hline $\begin{array}{l}\text { Directorate of Health (DIRESA) } \\
\text { of Loreto }\end{array}$ & Governing body of health at the regional level & City of Iquitos, Loreto \\
\hline $\begin{array}{l}\text { Office of Statistics of DIRESA } \\
\text { Loreto }\end{array}$ & $\begin{array}{l}\text { Office in charge of generating statistics of the National System of } \\
\text { Deaths }\end{array}$ & City of Iq \\
\hline First Level Health Facility & $\begin{array}{l}\text { Primary care health centre that serves the community and can } \\
\text { refer cases to hospitals }\end{array}$ & Rural area of Loreto \\
\hline $\begin{array}{l}\text { Regional (National) Hospital of } \\
\text { Loreto }\end{array}$ & $\begin{array}{l}\text { National Hospital funded by the Comprehensive Health } \\
\text { Insurance. }\end{array}$ & City of Iquitos, Loreto \\
\hline Hospital EsSalud & Workers' hospital financed by Social Security & City of Iquitos, Loreto \\
\hline
\end{tabular}

with key informants within the institutions involved in death certification in Loreto, Peru, between April and August 2020. We then used the information collected to compare business process maps during the pandemic to before the pandemic.

\section{Sampling and recruitment}

We used a purposive sampling strategy to identify key informants from the institutions involved in death certification in Loreto, Peru, during the study period. To commence the study, we travelled to Iquitos, capital city of Loreto, and the Health Directorate of Loreto was consulted. There, the snowball method was used, where the participant could suggest another organisation or person to complete and/or enrich the information. The person in charge, official, technical team or best available user who was involved in the death certification process during the study period was considered a key informant. Then, a contact list was drawn up and a member of the research team scheduled face-to-face and virtual meetings to carry out the interviews and/or request documentation, after explaining the study to the possible participants.

Our sample consisted of 28 participants from the following organisations: MINSA, Directorate of Health of Loreto, Office of Statistics, Office of Epidemiology, First Level Health Establishment, Rapid Response Team for COVID-19, Regional Hospital of Iquitos, Hospital EsSalud de Iquitos and Funeral Homes (table 1). The stakeholders interviewed included very senior staff such as a managing director or executive director of the institution, technical staff including from the IT technical team and physicians. We were unable to recruit participants from official and unofficial cemeteries.

\section{Data collection}

We conducted a series of semistructured interviews between September 2020 and May 2021. We developed questions based on the enterprise architecture methodology and feedback from the research team. The questions included inquiries to understand changes in processes and information flows in a pandemic context, as well as the impact of these possible changes on the effectiveness of death certification. The interviews were conducted by telephone, videoconference and in person and lasted were of 30 to 45 minutes duration. The units of analysis included the transcripts and field notes taken by the research team during the interviews. Informed consent was obtained verbally from all participants prior to the interviews. We asked participants for permission to use anonymous citations prior to their inclusion in the report and/or publication.

\section{Data analysis}

We analysed the records of the interviews using an enterprise architecture approach, which provides a conceptual framework to describe and analyse the architecture of a system by developing process maps or graphical representations of end-to-end processes that describe the stakeholders and necessary activities to complete a process. ${ }^{30}$ Business process maps of the system before and during the pandemic were developed. Two members of the research team reviewed the records and the attached field notes. They then met to compare their interpretations of the data, reviewing it for clarity and completeness. Discrepancies were resolved through discussion and modifications to the process map were made, as necessary. Also, we used the recordings and written notes to list the main quotes that exemplify the changes encountered during the pandemic.

\section{Patient and public involvement}

During the planning stage of the study protocol, the study team met with the Loreto Health Directorate (DIRESA), who informed us of the need to know the real number of deaths. For this, we proposed as a first stage to understand how the certification of deaths during the pandemic had occurred through a mapping of processes and interviews. The participants (ie, respondents from the institutions) 
did not participate directly in the design of the study, but the study team did coordinate with the DIRESA of Loreto who had seen the study protocol and provided access to the first participants to interview. The participants could suggest other possible key actors within the process to include in the study (ie, snowball methodology). The results of the study have been sent to the region by letter and the report addressed to the director general of the DIRESA of Loreto.

\section{RESULTS}

\section{Overview}

We interviewed 28 key informants. Of these, 17 (60.7\%) participants were women and $11(39.3 \%)$ men. All participants agreed that the death certification process was majorly impacted during the pandemic, especially between April and June, when the 'wave' peaked. We systematised the narratives of the participants about the intervening actors and the processes that changed during the pandemic.

The existing process of death certification in Peru is described in online supplemental file 1. Briefly, there are two stages. First, a medical death certificate is issued by a doctor who knew the patient or who confirmed the death using the online SINADEF or using a paper format, which is then entered into SINADEF. Next, to obtain a death certificate issued by the National Registry of Identification and Civil Status (RENIEC), which is the final document with legal value, it is mandatory for the family to visit a civil registry office with the medical death certificate in physical form (printed or original). The family is usually the one who takes care of all the procedures to obtain the certification, although funeral homes also offer to do all the paperwork. There are several points where the process can be interrupted, and it is entirely up to the family to choose whether to report the death, obtain a certificate and how to dispose of the body.

\section{Actors}

As a first step, we identified the actors involved in the death certification process in Loreto, Peru. The number of actors involved increased from 13 before the pandemic to 21 during the pandemic (or $62 \%$ more (table 2)). Also, the interactions between the different actors before and during the pandemic are shown in figures 1 and 2). The family of the deceased acts as the main axis of the certification process. Before the pandemic, the family needed to interact with up to 10 institutions to complete the death certification process. During the pandemic, this interaction took place with up to 19 institutions. This increase in interactions is explained by the burden of the family to complete the different administrative tasks of the death certification process. Funeral homes, in addition to helping with burial, could take over all administrative tasks at the request of family members, placing it as another main node in the process.

\section{Impact of the pandemic on death certification}

Interviews and documentary analysis showed that there were important changes during the studied months of the COVID-19 pandemic in Loreto. The period from April to August 2020, in particular, was characterised by a collapse of the health system caused by the enormous overload of patients and the limited availability of both human and material resources. Full description of these impacts is shown in online supplemental file 2).

- Large number of deaths per day

During the week of May 3-9, Loreto's health sector reported more than seven times the weekly historical average number of deaths, but the interviewees affirmed that this mortality was underestimated by approximately between $20 \%$ and $30 \%$. A large number of deaths occurred both in hospitals and in the community, and that they could not cope with the removal and storage of the corpses.

"That week was terrible, there was no way to prioritize places, people died at home. At the hospital, people died in the same queue waiting for care. In a single day I collected more than 40 corpses in the hospital, thank God the army supported us." (Loreto, 2021)

\section{- Fear of handling corpses}

The fear of the corpses of people suspected of having COVID-19 was present during the first 6 months of the pandemic. A MINSA regulation in March 2020 called for cremation only and did not allow family members to approach the corpses, and later when burials were allowed, there was fear in the population of being infected by contact with the corpse. Many people did not respond to the call to mobilise the corpse and/or collect the documents.

- Establishment of new entities to respond to the pandemic

An office of DIRESA Loreto, the Directorate of Environmental Health (DESA), was activated as responsible for a new function: the removal of corpses and their mobilisation to the crematorium or cemeteries called COVID-19 cemeteries. However, interviewees reported that due to the shortage of available doctors, there were cases in which the DESA was able to remove the body, many times without the express notification of the family, due to current regulations or due to the lack of response of the relatives to the call. In these cases the death certificate was not issued, leaving the family's responsibility to insist on producing the medical certificate of death.

- Opening of COVID-19 cemeteries

New cemeteries to bury the bodies of people suspected of COVID-19 appeared were created by the Regional Health Directorate due to the large number of corpses they had to handle, with mass graves where 3-4 corpses were buried in the same space. In these places, it was not necessary to have a death certificate.

- Loss of corpses 
Table 2 Actors involved in death certification

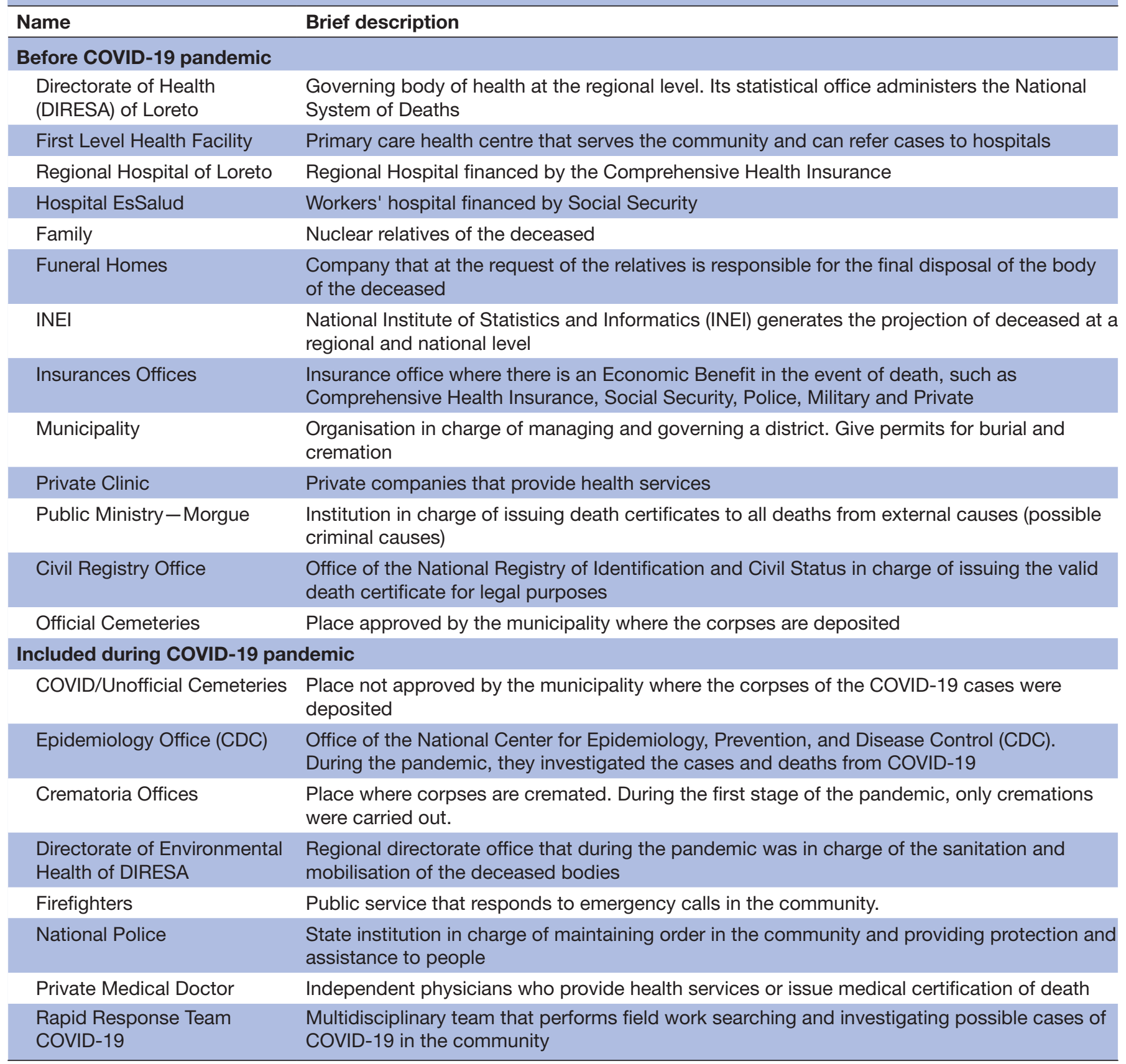

The loss of bodies was a major problem during the pandemic, which led to no medical death certificate being issued. In health facilities, it was reported that some family members, due to fear, took the body away before the staff could notify DESA to take it to a COVID-19 cemetery. This may have led to COVID-19 deaths being affected more by registration system disruptions more than for non-COVID deaths. Another issue was overcrowding, with non-medical personnel sending bodies to DESA even before notifying the treating doctor or the family.

"People took the corpses because they were afraid that they would be cremated, or that they would take them away and never hear from him again." (Loreto, 2020)

"It was chaos, my brothers called and said their seamstress, their neighbor and her friend had died but they don't know where they are." (Loreto, 2020)

- Greater participation of funeral homes in the certification process

During the pandemic, funeral homes played a greater role during the death certification process to assist families due to the increased burden of deaths, especially where they did not want the deceased to be buried in a COVID cemetery. However, it was reported 


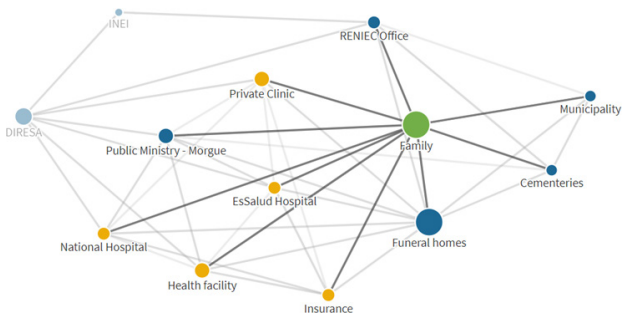

Figure 1 Actors involved in death certification before COVID-19 pandemic, Loreto each node represents an institution or individual that participates in the death certification process. The green colour represents the family, the yellow colour represents institutions related to the provision of health services and the blue colour represents civil and social organisations (eg, cemeteries, funeral homes, civil registry offices, municipalities). DIRESA, Loreto Health Directorate; INEI, National Institute of Statistics and Informatics; RENIEC, National Registry of Identification and Civil Status.

that in several cases the intervention of the funeral home was counterproductive because they issued many medical death certificates on paper which were not sent to DIRESA. Of those that did arrive, they were in outdated formats or, because they were photocopies, there were many paper certificates with the same serial number.

- Closure of the civil registry office

During the pandemic, civil registry offices were closed and all procedures were carried out virtually. Obtaining the RENIEC death certificate could only be carried out if the medical death certificate had been conducted online through SINADEF. If the medical death certificate had been issued on paper, the process could not be carried out and it was up to the family to try to have the medical death certificate issued again through SINADEF.

"If the funeral home did not make a medical death certificate with SINADEF, they could not have the certificate, Reniec would not accept it. There,

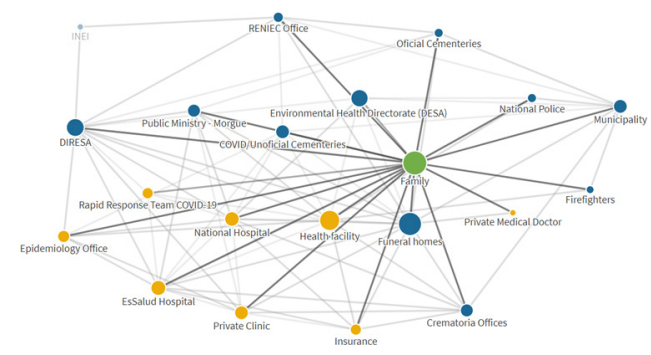

Figure 2 Actors involved in death certification during COVID-19 pandemic, Loreto each node represents an institution or individual that participates in the death certification process. The green colour represents the family, the yellow colour represents institutions related to the provision of health services and the blue colour represents civil and social organisations (eg, cemeteries, funeral homes, civil registry offices, municipalities). DIRESA, Loreto Health Directorate; RENIEC, National Registry of Identification and Civil Status. several were lost, several deaths were never registered." (Loreto, 2020)

- More use of SINADEF online

The increase in the number of medical death certificates made with SINADEF online caused issues, because doctors did not want to use the online system due to poor internet or lack of computers. However, the number of certificates using SINADEF online increased because the families demanded that the medical death certificate be issued online.

- More than one medical death certificate per person There was a high number of cases in which two or more medical death certificates issued in the name of the same person were found. This was due to a paper medical death certificate being completed again using SINADEF online to access a death certifyicate issued by RENIEC, or families obtaining a new certificate due to fear that the diagnosis of COVID-19 would appear as the cause of death, which would make the wake, burial and possible transfer of the body impossible.

\section{Key changes in death certification process before and during the pandemic}

During the interviews, we identified the processes and subprocesses to report and certify a death before and after the COVID-19 pandemic for deaths that occurred in a health facility and in the community. The narrative detail and maps of the processes in each scenario are shown in online supplemental file 1 , and a summary presented in table 3 .

During the pandemic, situations arose where a death could be left without registration in SINADEF. This included when the family, for fear of the loss of the body, removed the body from the health facility before notifying the physician or when hospital staff sent the body to a COVID-19 cemetery before to coordinate the notification of the treating physician. Also, due to the RENIEC death certificate only being able to be obtained if the medical death certificate had been made with SINADEF online, family members of those cases who had a paper medical death certificate had to return to the health centre to request a new one, find another doctor to make a new certificate using SINADEF online, or simply stopped trying and that death was not registered in RENIEC.

Another situation, when a death occurred in the community, was that instead of the family notifying a doctor to issue a medical death certificate, the family could request help from funeral homes, which offer a medical contact to evaluate the case and issue the medical death certificate (often discreetly because this is not part of the funeral home's official services). In those cases, if the certificate is completed by paper and not online, the death would not be registered in SINADEF.

Finally, during the pandemic, there were deaths in the community that did not occur at home (ie, in public places). In those cases, police, firefighters or social security intervened to call DESA and remove the body. If no 
Table 3 Summary table death certification processes before and during COVID-19 pandemic

\section{Death in a health facility}

Before COVID-19 pandemic During COVID-19 pandemic Death occurs

Treating physician is notified Could be various scenarios:

\section{Death in community \\ Before COVID-19 pandemic}

During COVID-19 pandemic

The family can choose not to inform, and they bury the body on their own.* Directorate of Environmental Health remove the corpse and
If death occurs outside the house, send it to COVID crematorium or cemetery ${ }^{*}$

- The family, fearing the loss If the family want to inform, a If death occurs in the house, the of the body, remove the body before notifying*

be: be:

- A physician who knows the case and works in a health facility body to a COVID cemetery before notifying the treating physician*

- Treating physician is notified and can continue with the following processes
A physician who knows A physician who knows the the case but doesn't work in a health facility case and works in a health facility

- A physician who doesn't know the case but is brought by the funeral home to evaluate the case

A physician who knows the case but doesn't work in a health facility

Physician issues the medical Physician issues the medical death certificate death certificate

- It can be done using National Death System (SINADEF) online

- Or it can be done using paper format. (A copy is sent to register in SINADEF)

Or it can be done using paper format. (A copy is sent to register in SINADEF)
The family can decide whether The family can decide to continue with the following whether to continue with processes to obtain the death the following processes to certificate (legal)

If not, they bury the body on their ownt

obtain the death certificate (legal)

If not, they bury the body on their ownt
- If not, they bury the body on their ownt
A physician who doesn't know the case but is brought by the funeral home to evaluate the case.

- A physician from the rapid response team who doesn't know the case but goes to the house to evaluate the case death certificate

- It can be done using SINADEF online

- Or it can be done using paper format. (Only if the doctor works in a health establishment or in the rapid response team, a copy is sent to register in SINADEF, if not the death is not registered in SINADEF)*

The family can decide whether to continue with the following processes to obtain the death certificate (legal)

If not, they bury the body on their ownt 


\begin{tabular}{|c|c|c|c|}
\hline \multicolumn{2}{|l|}{ Death in a health facility } & \multicolumn{2}{|l|}{ Death in community } \\
\hline Before COVID-19 pandemic & During COVID-19 pandemic & $\begin{array}{l}\text { Before COVID-19 } \\
\text { pandemic }\end{array}$ & During COVID-19 pandemic \\
\hline $\begin{array}{l}\text { If so, they (or funeral } \\
\text { home) must go to the civil } \\
\text { registry offices }\end{array}$ & $\begin{array}{l}\text { If so, they (or funeral home) } \\
\text { must access to National } \\
\text { Registry of Identification } \\
\text { and Civil Status (RENIEC) } \\
\text { website }\end{array}$ & $\begin{array}{l}\text { If so, they (or funeral } \\
\text { home) must go to the civil } \\
\text { registry offices }\end{array}$ & $\begin{array}{l}\text { If so, they (or funeral home) } \\
\text { must access to RENIEC } \\
\text { website }\end{array}$ \\
\hline
\end{tabular}

\section{Obtaining death certificate}

Civil registry office accepts

only medical death certificate, in physical form (printed or handwritten)

Civil registry office issues death certificate
RENIEC website initiate the process only if medical death certificate was made in SINADEF online

Civil registry office accepts only medical death certificate, in physical form (printed or handwritten)

Civil registry office issues

If not, the family must obtain a new medical death death certificate certificate issued by using SINADEF online or to stop in this step and bury the body on their ownt

$\begin{array}{ll}\text { Can be done using } & \text { If so, RENIEC website } \\ \text { RENIEC system online } & \text { issues death certificate } \\ & \text { using RENIEC system } \\ & \text { online }\end{array}$

- Can be done in paper

With the death certificate, the With the death certificate, the family can request permission family can request permission for burial in an official cemetery for burial in an official cemetery

\section{Using of the data}

\begin{tabular}{|c|c|c|c|}
\hline $\begin{array}{l}\text { MINSA uses the data } \\
\text { registered in SINADEF }\end{array}$ & $\begin{array}{l}\text { MINSA uses the data } \\
\text { registered in SINADEF }\end{array}$ & $\begin{array}{l}\text { MINSA uses the data } \\
\text { registered in SINADEF }\end{array}$ & $\begin{array}{l}\text { MINSA uses the data registered in } \\
\text { SINADEF }\end{array}$ \\
\hline $\begin{array}{l}\text { RENIEC uses the data } \\
\text { registered in RENIEC system }\end{array}$ & $\begin{array}{l}\text { RENIEC uses the data } \\
\text { registered in RENIEC system }\end{array}$ & $\begin{array}{l}\text { RENIEC uses the data } \\
\text { registered in RENIEC system }\end{array}$ & $\begin{array}{l}\text { RENIEC uses the data registered } \\
\text { in RENIEC system }\end{array}$ \\
\hline $\begin{array}{l}\text { INEI uses the aggregated } \\
\text { data sent by MINSA and } \\
\text { RENIEC }\end{array}$ & $\begin{array}{l}\text { INEI uses the aggregated data } \\
\text { sent by MINSA and RENIEC }\end{array}$ & $\begin{array}{l}\text { INEI uses the aggregated } \\
\text { data sent by MINSA and } \\
\text { RENIEC }\end{array}$ & $\begin{array}{l}\text { INEI uses the aggregated data } \\
\text { sent by MINSA and RENIEC }\end{array}$ \\
\hline
\end{tabular}

*Death is not registered in SINADEF or RENIEC.

†Death is registered in SINADEF but not in RENIEC.

responsible family member was found, the body was sent to a COVID-19 cemetery without issuing a death certificate. Another important change during the pandemic is that if the deceased had not been known to a doctor and the family could not access or did not want the help of funeral homes, the family then had to contact the rapid response team who came to the home, confirmed the death and issued the medical death certificate. It is reported that the doctors of the rapid response team, who made the certificate by hand in paper format, did generate an extra copy to send it to a DIRESA digitisation point for entry to SINADEF.

\section{DISCUSSION}

The COVID-19 pandemic in Loreto, Peru, led to substantially more deaths per day and strained the health system significantly. This study shows how the COVID-19 pandemic substantially disrupted the death certification process, which was already producing less than complete data before the pandemic, causing more potential issues to arise so that deaths are not registered (eg, caused by problems of removal and storage of the corpses, issues of fear of handling corpses and loss of corpses), more burden on the family (having to take care of additional paperwork, not knowing what process to follow, or interacting with more institutions) and leading to greater participation from unregulated organisations such as funeral homes or cemeteries. While these impacts were mainly 
due to new changes such as work overload in the health system, poor communication of new ways of working and the community's fear of being infected by corpses, they were also caused by limitations of the existing processes of the death certification system before the pandemic.

Since 2015, Peru, in conjunction with the Bloomberg Philanthropies Data for Health Initiative, initiated a series of interventions to improve its CRVS system, which included the strengthening of the medical death certificate registration system (SINADEF) and the registration system of deaths in Civil Registries (RENIEC) $1{ }^{15}$ As a consequence of this, the Peruvian government created various regulations for how the death registration process should operate, such as the directive for the certification of deaths, the technical guide on the correct completion of death certificates and the law of cemeteries and funeral services. ${ }^{16} 173132$ However, there are several regulated processes that were already not being followed, due to the little diffusion of the regulations and little supervision of their compliance due to not being sanctioned, and which were exacerbated during the pandemic according to evidence from this study.

The previously identified problematic situation of doctors giving the family member the complete form without sending the lower part to MINSA, although it existed before, worsened during the pandemic, where due to the scarce attention in health facilities, private doctors and doctors recommended by funeral homes participated to a greater extent in the issuance of paper medical death certificates. ${ }^{33} 34$ Another problem during the pandemic was the large circulation of obsolete forms of paper medical death certificates which could not be entered correctly in SINADEF due to funeral homes, because of a need to meet demand, generally using photocopies of obsolete formats with the same serial number.

Not having all the real processes identified, nor having a regulation adapted to them, entails a greater burden on the family, who had the main responsibility for compliance with mortality registration processes. During the pandemic, the family could potentially interact with up to 19 different institutions to complete the mortality registration process. In addition, it was solely up to the family to decide whether to notify the death, obtain a certificate or not, and consider the best way to dispose of the body. During the pandemic months studied, there was no possibility of a death being recorded in the RENIEC but not in the SINADEF because the RENIEC virtual offices only started the process if the medical death certificate had been made with SINADEF. This probably caused an increase in cases with a paper medical certificate of death where the family no longer wanted to continue with the process and that death ended without registration in SINADEF or RENIEC.

Finally, the changes produced by the COVID-19 pandemic also had the potential to impact the completeness of the Peruvian CRVS registry, both positively and negatively. Although it cannot be quantified with precision based on the findings of our study, the majority of those interviewed consider that at least 20\%-30\% more deaths occurred than what was registered in the SINADEF or RENIEC systems. While these disruptions would have had some negative impact on completeness compared with earlier years, it is possible that not all the changes were detrimental to the system. There was an increase in the use of the online platform, mainly due to the closure of civil registry offices who were not accepting any paper documents. Doctors and health establishments who previously had only used paper and were reluctant to use the online platform had to commence using SINADEF, with 3000 doctors supported in this by the College of Physicians of Peru. ${ }^{35}$ This could also be explained by the population beginning to demand that the medical death certificate be made only through the SINADEF, because otherwise RENIEC would not be able to generate a death certificate with legal value. This reported phenomenon is consistent with what was found in subsequent mortality reports from Loreto where, despite the end of the 'first wave' and a decrease in new cases, the number of deaths registered in SINADEF now remains above what reported in previous years. ${ }^{3637}$ Some of this increase in registered deaths could be due to continued impacts of the pandemic on actual mortality, as well as improved timeliness of registration because of the efficiency of the online system; further research is required to assess whether, and to what extent, completeness in all regions of Peru changed during the pandemic. Any increase in completeness of SINADEF during the pandemic would have implications for the measurement of excess mortality.

This is one of the first studies to show how a pandemic such as COVID-19 has affected death registration processes, and the first that we are aware of that has conducted in-depth interviews with key informants within the system. ${ }^{11}{ }^{12}$ It is important to consider that all the results found in this study are in the context of the most critical period of the first wave of the COVID-19 pandemic in the Loreto region. It was precisely during April and August 2020 that Loreto became the first region of Peru to exceed its historical weekly average of deaths by more than seven times, a situation that has not since repeated. ${ }^{37} 38$ The results obtained in this study, therefore, reflect the changes produced in a period of crisis and that could occur again if the appropriate measures are not taken to improve the processes. The findings also are based on interviews with representatives from various institutions involved in death certification, but did not include the perspectives of families. The findings can serve to prepare for future outbreaks or pandemics, not only in Peru but in other countries with similar CRVS system characteristics. For example, deficiencies in the CRVS system are likely to be exacerbated during the pandemic, as shown with the problems in Peru caused by lack of supervision of death certificate data collection. Hence, countries should endeavour to conduct in-depth assessments of their system and seek to rectify such issues, which will help the system be produce better quality data at all times and not just in a pandemic. Additionally, 
countries should seek to digitise their system which this study showed to be more resilient during a pandemic than paper-based systems.

\section{CONCLUSION}

The mortality registration process in Loreto, Peru, before and during the COVID-19 pandemic shows a high degree of fragmentation with little coordination and little knowledge of the regulations between the different actors. There are actors that became more relevant during the COVID-19 pandemic and that are not part of the official CRVS process. It is necessary to specifically regulate the role of funeral homes and cemeteries in supporting the medical certification and registration of the deceased in SINADEF and RENIEC. Including sanctions and those responsible for supervising such support. It is also important to adapt the regulations and strengthen the role of MINSA and DIRESA as health authorities for the effective control of medical death certification online and on paper. This includes effective coordination to redesign the processes with all the actors that actually interact in the mortality registration process. Process mapping studies are necessary to show how processes actually occur and if what is regulated is in accordance with reality. It is suggested to use these results as a first step to generate a more integrated and complete mortality registry system.

Acknowledgements The authors acknowledge the Regional Directorate of Loreto, especially the health personnel of the headquarters and the statistics department, who provided us with the facilities and logistical support necessary to carry out the interviews and process mapping.

Contributors JS-V participated in the conception of the research, data collection, data analysis, the writing of the article and approval of the final version of the article to be published, and is responsible for the overall content as the guarantor. TA participated in the conception of the research, review of the preliminary data, in the writing of the article and approval of the final version. $\mathrm{JH}$ participated in the conception of the research, review of the preliminary data and approval of the final version. GM participated in the conception of the research, in the data collection, writing of the article and approval of the final version. JVH participated in the conception of the research, in the data collection, data review, writing of the article and approval of the final version.

Funding This study was conducted during the civil registration and vital statistics (CRVS) Fellowship of JS-V. The CRVS Fellowship Program was funded under an award from Bloomberg Philanthropies and the Australian Department of Foreign Affairs and Trade to the University of Melbourne to support the Data for Health Initiative (grant number N/A). The funders had no role in study design, analysis and preparation of the manuscripts or decision to publish.

Competing interests None declared.

Patient consent for publication Not required.

Ethics approval Ethics approval was obtained from the Ethics Boards of the Universidad Nacional Mayor de San Marcos (CIEl-2021-08) in Lima, Perú.

Provenance and peer review Not commissioned; externally peer reviewed.

Data availability statement Data relevant to the study have been included in the article and as supplementary information. Further data are available from the authors upon reasonable request.

Supplemental material This content has been supplied by the author(s). It has not been vetted by BMJ Publishing Group Limited (BMJ) and may not have been peer-reviewed. Any opinions or recommendations discussed are solely those of the author(s) and are not endorsed by BMJ. BMJ disclaims all liability and responsibility arising from any reliance placed on the content. Where the content includes any translated material, BMJ does not warrant the accuracy and reliability of the translations (including but not limited to local regulations, clinical guidelines, terminology, drug names and drug dosages), and is not responsible for any error and/or omissions arising from translation and adaptation or otherwise.

Open access This is an open access article distributed in accordance with the Creative Commons Attribution Non Commercial (CC BY-NC 4.0) license, which permits others to distribute, remix, adapt, build upon this work non-commercially, and license their derivative works on different terms, provided the original work is properly cited, appropriate credit is given, any changes made indicated, and the use is non-commercial. See: http://creativecommons.org/licenses/by-nc/4.0/.

ORCID iDs

Tim Adair http://orcid.org/0000-0002-1562-4452

John Hart http://orcid.org/0000-0002-9637-7974

Graciela Meza http://orcid.org/0000-0001-5752-8824

\section{REFERENCES}

1 World Health Organization. Who coronavirus (COVID-19) Dashboard with vaccination data. Geneva: World Health Organization, 2021. https://covid19. who.int/

2 World Health Organization. World health statistics 2021: monitoring health for the SDGs. Geneva: World Health Organization, 2021.

3 Mills SL, Abouzahr C, Kim J. Civil registration and vital statistics (CRVS) for monitoring the sustainable development goals (SDGs). Washington, DC: World Bank, 2017. http://documents1.worldbank. org/curated/en/979321495190619598/pdf/115150-WP-CRVS-forMonitoring-the-SDGs-web-version-May-18-2017-PUBLIC.pdf]

4 Lo S, Horton R. Everyone counts--so count everyone. Lancet 2015;386:1313-4.

5 AbouZahr C, de Savigny D, Mikkelsen L, et al. Towards universal civil registration and vital statistics systems: the time is now. Lancet 2015;386:1407-18

6 Phillips DE, AbouZahr C, Lopez AD, et al. Are well functioning civil registration and vital statistics systems associated with better health outcomes? Lancet 2015;386:1386-94.

7 Checchi F, Roberts L. Documenting mortality in crises: what keeps us from doing better. PLoS Med 2008;5:e146.

8 Setel P, AbouZahr C, Atuheire EB, et al. Mortality surveillance during the COVID-19 pandemic. Bull World Health Organ 2020;98:374.

9 United Nations Statistics Division. UNSD demographic statistics New York: United nations, 2020. Available: https://unstats.un.org/unsd/ demographic-social/crvs/

10 de Savigny D, Cobos Muñoz D. CRVS best-practice and advocacy. understanding CRVS systems: the importance of process mapping. Melbourne: University of Melbourne, 2018. www.mspgh.unimelb. edu.au/dataforhealth

11 AbouZahr C, Bratschi MW, Cercone E, et al. The COVID-19 pandemic: effects on civil registration of births and deaths and on availability and utility of vital events data. Am J Public Health 2021;111:1123-31.

12 Kelly M, Mathenge G, Rao C. Lessons learnt and pathways forward for national civil registration and vital statistics systems after the COVID-19 pandemic. J Epidemiol Glob Health 2021;11:262-5.

13 Financial Times. Coronavirus tracker: the latest figures as countries fight the Covid-19 resurgence. Available: https://www.ft.com/ content/a2901ce8-5eb7-4633-b89c-cbdf5b386938

14 Financial Times. Coronavirus chart: has your country's epidemic peaked? Financial Times. Available: https://ig.ft.com/coronaviruschart/?areas=usa\&areas $=$ gbr\&areas $=$ per\&areasRegional=usny $\&$ areasRegional=usca\&areasRegional=usfl\&areasRegional=ustx\& byDate $=0$ \& cumulative $=1$ \&logScale $=1$ \&perMillion $=1$ \&values $=$ deaths

15 Vargas-Herrera J, Ruiz KP, Nuñez GG, et al. Preliminary results of the strengthening of the national death registry information system. Rev Peru Med Exp Salud Publica 2018;35:505-14.

16 Ministerio de Salud. Resolución Ministerial N²80-2016-MINSA que aprueba Directiva Administrativa N²16-MINSA/OGTI-V.01: Directiva Administrativa que establece El Procedimiento para La Certificación de las Defunciones. Lima: Ministerio de Salud, 2016. https://www. gob.pe/institucion/minsa/normas-legales/192422-280-2016-minsa

17 Gobierno del Perú. Guía técnica para El correcto llenado del certificado de defunción. Lima: Gobierno del Perú, 2018. https:// www.gob.pe/institucion/minsa/informes-publicaciones/279679-guiatecnica-para-el-correcto-llenado-del-certificado-de-defuncion

18 RPP Noticias. Coronavirus en Perú | 100 días de cuarentena: un recuento analizado sobre el Estado de Emergencia por la COVID-19. Lima: RPP Noticias, 2020. https://rpp.pe/politica/estado/perucumple-100-dias-en-confinamiento-un-recuento-analizado-sobre-elestado-de-emergencia-por-la-covid-19-noticia-1274852 
19 Balance COVID-19. ¿Qué lecciones ha dejado la pandemia para el sector salud? Lima: RPP Noticias, 2021. https://rpp.pe/campanas/ valor-compartido/balance-covid-19-que-lecciones-ha-dejado-lapandemia-para-el-sector-salud-sistema-de-salud-minsa-essaludnoticia-1340954

20 Municipalidad Provincial del Callao. ¿Cuál es el protocolo a seguir para los fallecidos por COVID-19? Lima: Municipalidad Provincial del Callao, 2021. https://www.municallao.gob.pe/index.php/noticias/ 2609-cual-es-el-protocolo-a-seguir-para-los-fallecidos-por-covid-19

21 Gestión. Por el azote del COVID-19 se complican los entierros en Perú. Lima: Gestión, 2021. https://gestion.pe/peru/por-el-azote-delcovid-19-se-complican-los-entierros-en-peru-noticia/?ref=signwall

22 Adair T, Hudson S, Ad L. Approaches and methods for estimating excess deaths due to COVID-19. Melbourne: University of Melbourne, 2018. www.mspgh.unimelb.edu.au/dataforhealth

23 Sempé L, Lloyd-Sherlock P, Martínez R, et al. Estimation of all-cause excess mortality by age-specific mortality patterns for countries with incomplete vital statistics: a population-based study of the case of Peru during the first wave of the COVID-19 pandemic. Lancet Reg Health Am 2021;2:100039.

24 Diana Carolina CL, Mariam Gabriela DY, Javier SV. Estudio descriptivo de la conectividad móvil de establecimientos de salud MINSA del departamento de Loreto en la Amazonía del Perú. Cuba Salud, 2018. Available: http://convencionsalud2018.sld.cu/index. php/connvencionsalud/2018/paper/view/2091

25 Ministerio del Salud. Covid 19 en el Perú - Ministerio del Salud. Lima: Ministerio del Salud, 2021. https://covid19.minsa.gob.pe/sala_ situacional.asp

26 Galán-Rodas E, Tarazona-Fernández A, Palacios-Celi M. Riesgo y muerte de los médicos a 100 días del estado de emergencia por el COVID-19 en Perú. ACTA MEDICA Peru 2020;37:119-21.

27 Gestion. Perú: El pulmón del mundo se muere literalmente por falta de oxígeno. Lima: Gestion, 2021. https://gestion.pe/peru/el-pulmondel-mundo-se-muere-literalmente-por-falta-de-oxigeno-noticia/

28 Pampa-Espinoza L. Seroprevalencia de COVID-19 en trabajadores de un hospital de la Amazonía peruana. Acta Médica Peruana 2020;19.

29 Álvarez Antonio CA, Meza Sánchez GR, Calampa del Águila C. Seroprevalencia de anticuerpos anti SARS-CoV-2 en la ciudad de
Iquitos, Loreto, Perúdocx - Documentos de Google, 2020. Available: https://docs.google.com/document/d/1K-aKyFmxztdfNJOtXuSH1u GcBeaZA7LH/edit

30 Cobos Muñoz D, de Savigny D, Sorchik R, et al. Better data for better outcomes: the importance of process mapping and management in CRVS systems. BMC Med 2020;18:67.

31 Gobierno del Perú. Ley $N^{\circ} 26298$ | Ley de cementerios y servicios funerarios. Lima, 1994. Available: https://www.gob.pe/institucion/ minsa/normas-legales/256905-26298 [Accessed 19 Jun 2021].

32 Gobierno del Perú. Decreto Legislativo N 1503 | Decreto Legislativo que modifica la Ley No 26842, Ley General de Salud, y la Ley No 26298, Ley de Cementerios y Servicios Funerarios. Lima, 2020. Available: https://www.gob.pe/institucion/presidencia/normaslegales/575967-1503

33 Organización Panamericana de la Salud (PAHO). La COVID-19 afectó el funcionamiento de los servicios de salud para enfermedades no transmisibles en las Américas - OPS/OM. Washington DC: PAHO, 2020. https://www.paho.org/es/noticias/17-6-2020-covid-19-afectofuncionamiento-servicios-salud-para-enfermedades-no

34 Villanueva-Carrasco R, Dominguez Samamés R, Salazar de la Cruz M. Peruvian primary care response to the COVID-19 pandemic. An la Fac Med 2020;81:337-78.

35 Curioso $\mathrm{WH}$, Galan-Rodas E. The role of telehealth in the fight against COVID-19 and the evolution of the Peruvian regulatory framework. Acta Med Peru 2020;37 https://amp.cmp.org.pe/index. php/AMP/article/view/1004

36 Dirección de Epidemiología - DIRESA LORETO. Situación de la pandemia por COVID-19 y acciones desarrolladas en la Región Loreto, año 2020.(SE 30). Iquitos: DIRESA Loerto, 2020.

37 Silva-Valencia J, Vargas Herrera J. Exceso Mortalidad Perú semana 19-2021. Lima, 2020. Available: https://drive.google. com/file/d/19ETg7wSp90wfjU_I-QJdTeeYJ5FCSxmx/view?fbclid= IwAR0xL9RS24_vG12ucJF8wmJdliKKsLTG9wbFoqMcv6FmNGZ WUUPKGnIrIPc

38 Información de Fallecidos del Sistema Informático Nacional de Defunciones - SINADEF - [Ministerio de Salud]. Plataforma Nacional de Datos Abiertos. Lima: Ministerio de Salud, 2021. https://www. datosabiertos.gob.pe/dataset/información-de-fallecidos-del-sistemainformático-nacional-de-defunciones-sinadef-ministerio 